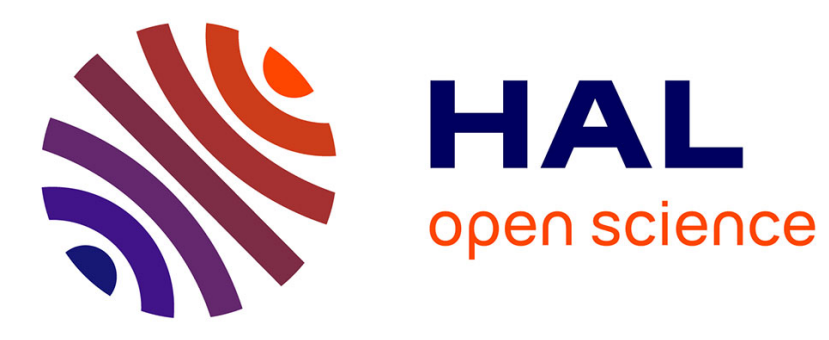

\title{
Effects of 2,4,6-trinitrotoluene (TNT) on phase I and phase II biotransformation enzymes in European eel (Linnaeus, 1758)
}

Camilla Della Torre, Ilaria Corsi, Augustine Arukwe, Luigi Alcaro, Ezio Amato, Silvano Focardi

\section{To cite this version:}

Camilla Della Torre, Ilaria Corsi, Augustine Arukwe, Luigi Alcaro, Ezio Amato, et al.. Effects of 2,4,6trinitrotoluene (TNT) on phase I and phase II biotransformation enzymes in European eel (Linnaeus, 1758). Marine Environmental Research, 2008, 66 (1), pp.9. 10.1016/j.marenvres.2008.02.008 . hal00501940

\section{HAL Id: hal-00501940 \\ https://hal.science/hal-00501940}

Submitted on 13 Jul 2010

HAL is a multi-disciplinary open access archive for the deposit and dissemination of scientific research documents, whether they are published or not. The documents may come from teaching and research institutions in France or abroad, or from public or private research centers.
L'archive ouverte pluridisciplinaire HAL, est destinée au dépôt et à la diffusion de documents scientifiques de niveau recherche, publiés ou non, émanant des établissements d'enseignement et de recherche français ou étrangers, des laboratoires publics ou privés. 


\section{Accepted Manuscript}

Effects of 2,4,6-trinitrotoluene (TNT) on phase I and phase II biotransformation enzymes in European eel Anguilla anguilla (Linnaeus, 1758)

Camilla Della Torre, Ilaria Corsi, Augustine Arukwe, Luigi Alcaro, Ezio Amato, Silvano Focardi

PII:

S0141-1136(08)00024-X

DOI: 10.1016/j.marenvres.2008.02.008

Reference: MERE 3176

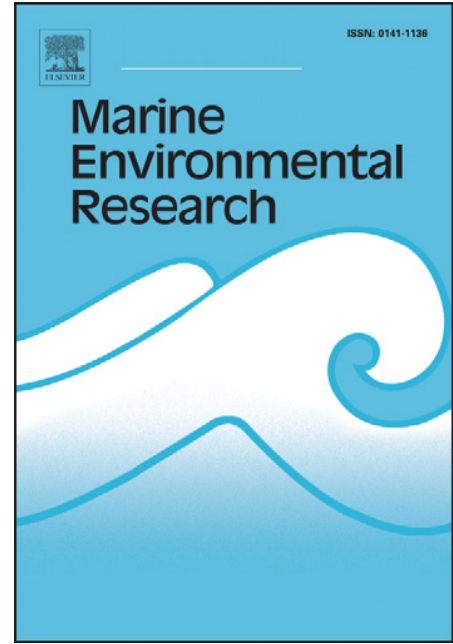

To appear in:

Marine Environmental Research

Please cite this article as: Torre, C.D., Corsi, I., Arukwe, A., Alcaro, L., Amato, E., Focardi, S., Effects of 2,4,6trinitrotoluene (TNT) on phase I and phase II biotransformation enzymes in European eel Anguilla anguilla (Linnaeus, 1758), Marine Environmental Research (2008), doi: 10.1016/j.marenvres.2008.02.008

This is a PDF file of an unedited manuscript that has been accepted for publication. As a service to our customers we are providing this early version of the manuscript. The manuscript will undergo copyediting, typesetting, and review of the resulting proof before it is published in its final form. Please note that during the production process errors may be discovered which could affect the content, and all legal disclaimers that apply to the journal pertain. 


\title{
Effects of 2,4,6-trinitrotoluene (TNT) on phase I and phase II biotransformation enzymes in European eel Anguilla anguilla (Linnaeus, 1758)
}

Camilla Della Torre ${ }^{\mathrm{a}, *}$, Ilaria Corsi ${ }^{\mathrm{a}}$, Augustine Arukwe ${ }^{\mathrm{b}}$, Luigi Alcaro ${ }^{\mathrm{c}}$, Ezio$$
\text { Amato }{ }^{c} \text {, Silvano Focardi }{ }^{a}
$$ \\ a Department of Environmental Sciences “G. Sarfatti”, University of Siena, Via Mattioli 4, 53100 Siena, Italy \\ ${ }^{\mathrm{b}}$ Department of Biology Norwegian University of Science and Technology (NTNU) Høgskoleringen 57491 \\ Trondheim Norway \\ ${ }^{\mathrm{c}}$ ICRAM Central Institute of Marine Research Via di Casalotti 30000166 Roma Italy
}

\begin{abstract}
The aim of this study was to investigate effects of the explosive 2,4,6-trinitrotoluene (TNT) on liver drug metabolizing genes and enzymes in the European eel Anguilla anguilla as a model fish species. Eels were exposed in vivo for $6 \mathrm{~h}$ and $24 \mathrm{~h}$ to $0.5,1$ and $2.5 \mathrm{mg} / \mathrm{L}$ nominal concentration of TNT. Expression of CYP1A, glutathione-S-transferase (pi-class; GST) and uridine-diphosphate glucuronosyltransferase (1-family) (UDPGT) genes was investigated by RT-PCR, and 7-ethoxy- and 7-methoxyresorufin- $O$-dealkylases (EROD, MROD), NADPH cyt c reductase (NADPH red), UDPGT and GST enzyme activities were measured by biochemical assays. An in vitro study was also performed, measuring only EROD activity. TNT exposure produced no modulation of CYP1A transcript expression
\end{abstract}


while a significant inhibition of EROD enzyme activity was observed and confirmed in vitro. UDPGT transcript increased dose-dependently only at $6 \mathrm{~h}$ while the UDPGT activity tended to increase dose-dependently at $24 \mathrm{~h}$. GST gene expression increased after $24 \mathrm{~h}$ and significant increases of GST activity were observed both at 6 and $24 \mathrm{~h}$ only at the highest TNT concentration. An increase of NADPH red activity was observed at $24 \mathrm{~h}$. Our results seem to indicate an inhibitory effect of TNT on CYP1A-dependent catalytic activity by TNT and a possible involvement of phase II enzymes as well as NADPH red in TNT metabolism in eels.

Keywords: 2,4,6-trinitrotoluene; CYP1A; GST; UDPGT; European eel

*Corresponding author: Tel: +390577 232877, Fax: +390577 232806

E-mail address: dellatorre2@unisi.it (C. Della Torre)

2,4,6-trinitrotoluene (TNT) is the one of the most common nitroaromatic explosives used in conventional bombs, and its presence in the marine environment is associated with extensive dumping of unexploded ordnance at sea. The acute and chronic toxicity of TNT have been reported for several aquatic species (Talmage et al., 1999), but few investigations have focused on the interaction of the compound with biochemical pathways in these organisms (Ek et al., 2005; Johnson et al., 2000).

The aim of the present study was to investigate the effects of TNT on phase I and phase II drug metabolizing genes and enzymes in liver of the European eel (Anguilla anguilla) as model fish species. The goal is to provide relevant information on the involvement of this system on TNT metabolism/toxicity and to identify possible biomarkers of TNT exposure. 
Eels were exposed for $6 \mathrm{~h}$ and $24 \mathrm{~h}$ to $0.5,1$ and $2.5 \mathrm{mg} / \mathrm{L}$ nominal concentrations of TNT using DMSO at $0.1 \%$ as a carrier. The TNT concentrations chosen were below or in the range of the 96-h LD50 calculated for fish $(0.8-3.7 \mathrm{mg} / \mathrm{L})$ (Talmage et al., 1999). Once absorbed by aquatic organisms TNT is readily metabolized with an half life measured in laboratory exposed fishes of $0.05 \mathrm{~h}$ (Ownby et al., 2005) and a very fast elimination. In this view the acute exposure via water was selected in order to evaluate noxious effects of the compound in the most realistic exposure condition occurring in the marine environment in dumping areas.

Possible effects of TNT on expression of CYP1A1, GST and UDPGT transcripts in liver were investigated by quantitative real-time PCR using primers designed from conserved regions of the selected genes using PCR designer software PRIMER3. Primer pair sequences and their amplicon size are shown in Table 1. EROD, MROD, NADPH reductase, GST and UDPGT activities were measured by biochemical assay following methods of Burke and Meyer (1974), Livingstone and Farrar (1984), Habig et al. (1974) and Collier et al.(2000), respectively. An in vitro study was also performed to evaluate the potential effect of TNT on the catalytic activity of CYP1A (EROD).

No modulation of CYP1A1 gene expression was observed within 24h of exposure whereas CYP1A enzyme activities were clearly affected by TNT (Fig. 1). EROD activity showed a significant decrease at the lowest concentration with respect to unexposed eels and a similar extent of decrease was observed at higher concentrations (Fig. 1). Inhibition of EROD activity was stronger at $24 \mathrm{~h}$, but again with no dose-dependent decrease. MROD seemed not to be affected after $6 \mathrm{~h}$ of exposure while a significant decrease was observed at $24 \mathrm{~h}$ from 7.13 $\pm 1.69 \mathrm{pmol} / \mathrm{min} / \mathrm{mg}$ prot in controls to $2.72 \pm 0.28 \mathrm{pmol} / \mathrm{min} / \mathrm{mg}$ prot at TNT highest concentration. The in vitro study confirmed TNT as an inhibitor of EROD activity with an IC50 of $82.6 \mu \mathrm{M}$. A significant increase in NADPH reductase activity was measured after 
$24 \mathrm{~h}$ of exposure with respect to controls at the highest concentration of TNT $(10.41 \pm 0.30 \mathrm{vs}$ $7.94 \pm 0.40 \mathrm{nmol} / \mathrm{min} / \mathrm{mg}$ prot Mann-Whitney U-test $\mathrm{p}<0.05)$. GST gene expression showed a dose-dependent increase at $24 \mathrm{~h}$ while GST activity significantly increased only at the highest TNT dose. TNT also dose-dependently increase the expression of UDPGT transcript at $6 \mathrm{~h}$, with significantly higher values relative to controls at 1 and $2.5 \mathrm{mg} / \mathrm{L}$, while UDPGT expression decreased slightly at 24h (Fig. 1). No effect was observed on UDPGT activity at $6 \mathrm{~h}$, while at $24 \mathrm{~h}$ activity was increased relative to controls, at the highest TNT concentration.

Our in vivo and in vitro results showing inhibition of EROD by TNT suggest that it could competitively inhibit oxidation of other substrates by CYP1A. Since TNT is metabolized within few hours of exposure (Ownby et al., 2005), aminated metabolite could, reasonably, be involved in generating the inhibitory effect. An active involvement of NADPH-dependent hepatic microsomal system in TNT metabolism could be hypothesised in agreement with previous findings in mammals (Leung et al., 1995). The dose-dependent increase of the phase II genes encoding UDPGT and GST and related catalytic activities, observed in TNT exposed eels, would be consistent with involvement of phase II enzymes in TNT metabolism. The active involvement of UDPGT and GST enzymes in TNT metabolism has been documented for different vertebrate species (Reddy et al., 2000; Ek et al., 2005). More specifically the study of Ek et al. (2005) indicates TNT exists in fish bile as glucuronide conjugates. In laboratory mammals a major portion of TNT metabolites is excreted as glucuronide conjugates (Talmage et al., 1999). The involvement of GST in response to TNT exposure is also suggested by Ek et al. (2005) and Johnson et al. (2000). Our hypothesis on the active involvement of phase II enzymes is thus strenghtened by the findings reported in literature. The time-response differences observed for UDPGT and GST genes and enzyme activities could be due to specific conjugation with distinct TNT metabolites generated at different times. GST in particular is involved in conjugation of electrophilic metabolites, with 
glutathione playing an important role in protecting tissues from oxidative damage. Therefore the increase in GST gene expression and related enzyme activity also suggests activation of antioxidant defences in TNT-exposed eels.

In conclusion, nitroaromatic explosives in the marine environment could modulate drug metabolizing genes and enzymes and increase the susceptibility of fish to toxic contaminants.

\section{References}

Burke, M.D., and Mayer, R.T. (1974). Drug Metabolism and Disposition, 2, 583-588.

Collier, A.C., Tingle, M.D., Keelan, J.A., Paxton, J.W., and Mitchell, M.D. (2000). Drug Metabolism and Disposition, 28, 1184-1186.

Ek, H., Dave, G., Sturve, J., Almroth, B.C., Stephensen, E., Förlin, L., et al. (2005). Aquatic Toxicology, 72, 221-230.

Habig, W.H., Pabst, M.J., and Jakoby, W.B. (1974). Journal of Biological Chemistry, 249, 7130-7139.

Johnson, M.S., Vodela, J.K., Reddy, G., and Holladay, S.D. (2000). Ecotoxicology and Environmental Safety, 46, 186-191.

Leung, K.H., Yao, M., Stearns, R., and Chiu, S-H.L. (1995). Chemico-Biological Interactions, $97,37-51$.

Livingstone, D.R., and Farrar, S.V. (1984). Science of the Total Environment, 39, 209-235.

Ownby, D.R., Belden, J.B., Lotufo, J.R., and Lydy, M.J. (2005). Chemosphere, 58, 11531159.

Reddy, G., Chandra, S.A.M., Lish J..W., and Qualls, C.W. (2000). International Journal of Toxicology, 19, 169-177. 
Talmage, S.S., Opresko, D.M., Maxwell, C.J., Welsh, C.J.E., Cretella, F.M., Reno, P.H., et al.(1982). Archives of Toxicology, 51, 53-64. 


\section{ACCEPTED MANUSCRIPT}

\section{Figure caption}

Fig 1. CYP1A (a), GST (c) and UDPGT (e) gene expression and related activity (b, d, f respectively) in eels exposed in vivo for $6 \mathrm{~h}$ and $24 \mathrm{~h}$ to $0.5,1$ and $2.5 \mathrm{mg} / \mathrm{L}$ nominal concentrations of TNT. DMSO at $0.1 \%$ orepresents the experimental control.

* significant difference with respect to DMSO group (Mann Whitney U-test $\mathrm{p}<0.05$ ). 
Table 1.

List of designed primer pair sequences and the expected amplicon size of CYP1A1, UDPGT1 and GST -pi

Target gene Primer sequence

Amplicon size

Forward

Reverse

(nucleotides)

CYP1A1

GGAGGGTGAGTACCTGGTGA

GAGTTCCTGGTCATCGTGGT

147

UDPGT1

ATAAGGACCGTCCCATCGAG

ATCCAGTTGAGGAAGG

GST-pi

ATCACCTACTTTGCGGTTCG

GGCCCAGATGTCTGAGGATA 208 
Figure 1
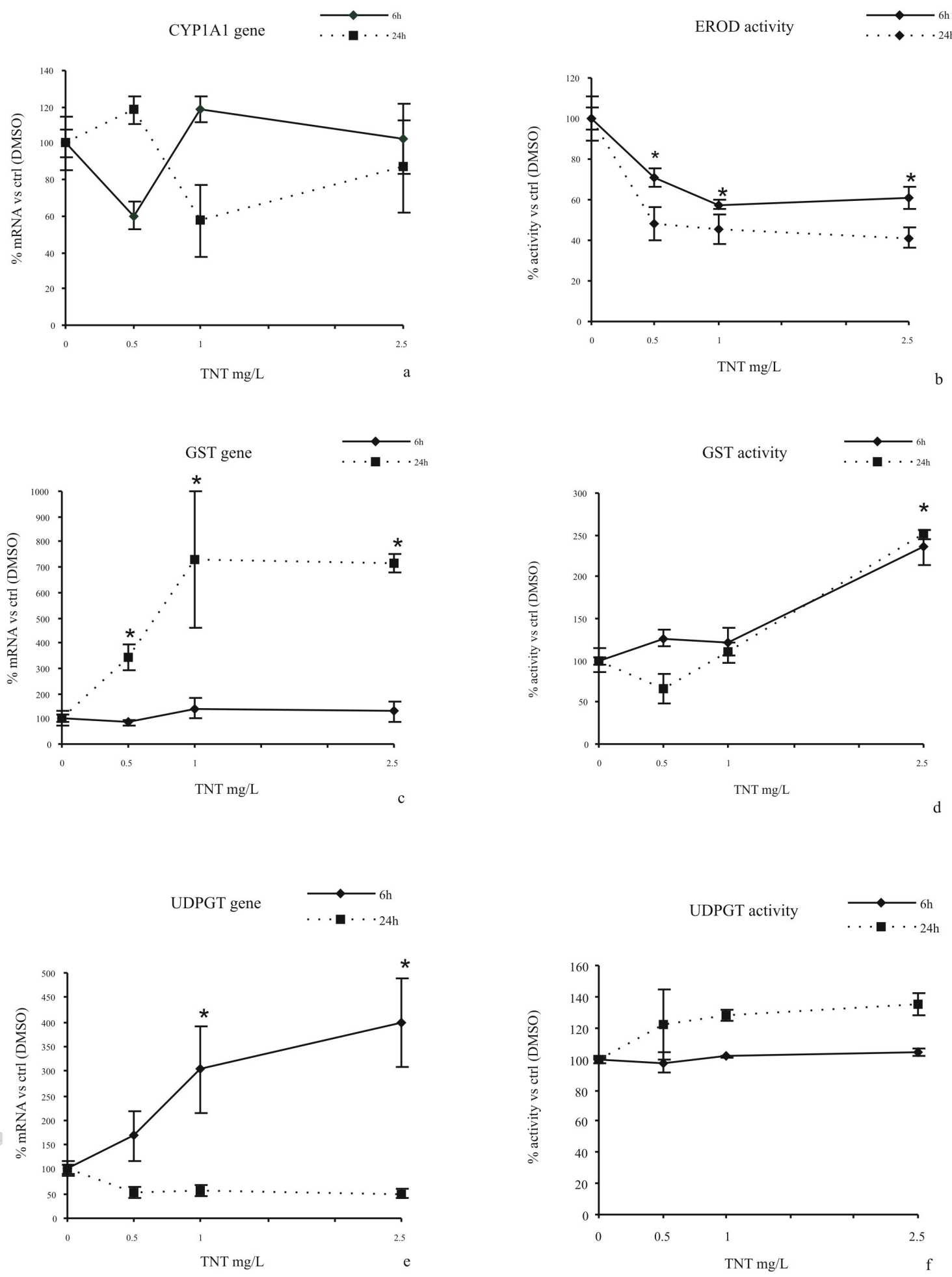